TABLE 1 tRNA synthetase interactions (distance $<3.5 \AA$ )

\begin{tabular}{|c|c|c|c|}
\hline \multicolumn{2}{|c|}{ tRNA } & \multicolumn{2}{|c|}{ AspRS } \\
\hline \multirow[t]{3}{*}{ U1 } & $\mathrm{OP}$ & Lys $293^{*}$ & $\mathrm{~N} \zeta$ \\
\hline & $\mathrm{OP}$ & Asn 328 & $\mathrm{~N} \delta$ \\
\hline & 04 & Asn 330 & $\mathrm{~N}$ \\
\hline \multirow[t]{2}{*}{ A72 } & $\mathrm{OP}$ & Lys 428 & $\mathrm{~N} \zeta$ \\
\hline & N6 & Asn 330 & 0 \\
\hline \multirow[t]{6}{*}{ G73 } & $\mathrm{OP}$ & Thr 424 & Oy \\
\hline & $\mathrm{OP}$ & Ser 423 & $0 \gamma$ \\
\hline & $06+$ & Thr 331 & $O y$ \\
\hline & $\mathrm{N} 1 \dagger$ & Ser 329 & $O y$ \\
\hline & $\mathrm{N} 2 \dagger$ & Asn 328 & 0 \\
\hline & $\mathrm{N} 2 \dagger$ & Glu 327 & $O_{\varepsilon}$ \\
\hline \multirow[t]{2}{*}{ C74 } & N3† & Ser 329 & $0 \gamma$ \\
\hline & $\mathrm{N} 4 \dagger$ & His 334 & $\mathrm{~N} \varepsilon$ \\
\hline $\mathrm{C} 67$ & $\mathrm{OP}$ & Lys 553 & $N \zeta$ \\
\hline U11 & $02^{\prime}$ & Asp 210 & $0 \delta$ \\
\hline \multirow[t]{2}{*}{ U12 } & OP & Thr 230 & $O \gamma$ \\
\hline & $\mathrm{OP}$ & Asn 227 & $N$ \\
\hline G27 & $\mathrm{O} 2^{\prime}$ & Glu 202 & $\mathrm{O} \varepsilon$ \\
\hline G30 & $O P$ & Lys 155 & $\mathrm{~N} \zeta$ \\
\hline$\Psi 32$ & N3 & Gln 120 & 0 \\
\hline U33 & 04 & Thr 124 & $O \gamma$ \\
\hline \multirow[t]{2}{*}{ G34 } & N7 & Lys 142 & $\mathrm{N \zeta}$ \\
\hline & N2 & Glu 188 & $0 \varepsilon$ \\
\hline \multirow[t]{4}{*}{ U35 } & $04^{\prime}$ & Gln 121 & $\mathrm{~N} \varepsilon$ \\
\hline & N3 & Gln 138 & $0 \varepsilon$ \\
\hline & 02 & Arg 119 & $\mathrm{~N} \eta$ \\
\hline & - & Phe 127 & Stacking \\
\hline \multirow[t]{4}{*}{ C36 } & $04^{\prime}$ & Arg 119 & $\mathrm{~N} \eta$ \\
\hline & 02 & Ser 181 & Oy \\
\hline & $\mathrm{O} 2$ & Lys 180 & $\mathrm{~N}$ \\
\hline & N4 & Pro 178 & 0 \\
\hline m1G37 & $\mathrm{OP}$ & Lys 180 & $\mathrm{~N} \zeta$ \\
\hline \multirow[t]{3}{*}{ C38 } & OP & Asn 117 & $\mathrm{~N} \delta$ \\
\hline & N4 & Gln 120 & 0 \\
\hline & N3 & Gln 121 & $0 \varepsilon$ \\
\hline
\end{tabular}

Interactions within the active site (nucleotides C75 and A76) are not included. Residues in bold are highly conserved in all AspRS, whereas those in italics are conserved in eukaryotes only. In tRNA, phosphate oxygens are named OP, atoms with primes belong to the ribose, all others to the base.

* This residue belongs to the other subunit.

$\dagger$ The conformations are different in the two subunits. In the map of the binary complex the active sites are different in the two subunits. In subunit $B$, although the crystals were grown in the absence of ATP in the mother liquor, a clear electron density is visible in which an AMP model can be fitted. In the other subunit, this site is partially occupied by the terminal adenosine of tRNA as a result of a conformational change which extends up to the first base pair of the acceptor stem. In subunit B, where the CCA end of tRNA occupies its functional location, A76 is stacked on Phe 304 with its ribose group above and close to the $\beta$ phosphate of ATP. The ATP binding site essentially comprises the class II conserved Glu 327 and Phe 338 (stacked on the purine ring) and the glycine-rich strand of motif 3 (Gly 526 -Gly 528) which interacts with the ribose-phosphate groups. The invariant residues of motifs 2 and 3 bind to the $\alpha$-phosphate (Arg 325) and to the ribose (Arg 531). Addition of ATP to the crystals leads to fully symmetrical dimers. A detailed analysis of the structure-function relationship in the active site will be published (J.C. et al., manuscript in preparation).

II aaRS. Subgroup specificity is then obtained by the addition of a module at the N-terminal end. Another module, not conserved in prokaryotic AspRS, is inserted after the conserved motif 2 of class II and plays an important role in the specific recognition of tRNA. An additional recognition element interacting with the minor groove of the acceptor stem may be present in some class II enzymes, for example in the E. coli AlaRS system where the main tRNA identity determinant is the third base pair of the acceptor stem ${ }^{23,24}$. The insertion peptide after motif 2 could also act as a minor groove recognition module.
Received 24 August; accepted 22 December 1992.

1. Eriani, G., Delarue, M., Poch, O., Gangloff, J. \& Moras, D. Nature 347, 203-206 (1990).

Webster, T. Tsai, H. Kula, M. Mackie, G. A \& Schimmel, P Science 226, 1315 1317 (1984)

3. Hountondji, C., Dessen, P. \& Blanquet, S. Biochimie 68, 1071-1078 (1986)

4. Fraser, T. H. \& Rich, A. Proc. natn. Acad. Sci. U.S.A. 72, 3044-3048 (1975

5. Von der Haar, F. \& Cramer, F. Biochemistry 15, 4131-4136, (1976).

6. Hecht. S. M. Transfer RNA: Structures, Properties and Recognition (eds P. P. Schimmel, D. Söll \& J. N. Abelson) 345-360 (Cold Spring Harbor Laboratory Press, New York, 1979).

7. Cusack, S. Härtlein, M. \& Leberman, R. Nucleic Acids Res. 19, 3489-3498 (1991)

8. Moras, D. Trends biochem. Sci. 17, 159-164 (1992).

9. Brick, P., Bhat, T. N. \& Blow, D. M. J. molec. Biol. 208, 83-98 (1989).

10. Brunie, S., Zelwer, C. \& Risler, J. L. J. molec. Biol. 216, 411-424 (1990).

11. Rould, M. A., Perona, J. J., Söll, D. \& Steitz. T. A. Science 246, 1135-1142 (1989)

12. Cusack, S., Berthet-Coiominas, C., Härtiein, M., Nassar, N. \& Leberman, R. Nature 347, 249-255 (1990)

13. Ruff, M. et at. Science 252, 1682-1689 (1991).

14. Pütz, J., Puglisi, J. D. Florentz, C. \& Giegé, R. Science 252, 1696-1699 (1991).

15. Hynes. T. R. \& Fox, R. O. Proteins 10, 92-105 (1991).

15. Hynes, T. R. \& Fox, R. O. Proteins 10, 92-105

16. Sixma, T. K. Nature 355, $561-564$ (1992).

17. Stein, P. E., Boodhoo, A., Tyrrell, G. J., Brunton, J. L. \& Read, R. J. Nature 355, 748-7
18. Eriani, G., Dirheimer, G. \& Gangloff, J. Nucleic Acids Res. 18, 7109-7117 (1990)

19. Anselme, J. \& Hartiein, M. Gene 84, 481-485 (1989).

20. Leveque, F., Plateau, P., Dessen, P. \& Blanquet, S. Nucleic Acids Research 18, 305-312 (1990)

21. Moras, D. et al. Nature 288, 669-674 (1980).

22. Westhof, E., Dumas, P. \& Moras, D. J. molec. Biol. 184, 119-145 (1985).

23. McClain, W. H. \& Foss, K. Science 241, 1804-1807 (1988)

24. Hou, Y. M. \& Schimmel, P. Nature 333, 140-145 (1988).

25. Kraulis, P. J. J. appl. Crystallogr. 24, 946-950 (1991).

25. Kraulis, P. J. J. appl. Crystallogr. 24, 946-950 (1991).

27. Brünger, A. T. J. molec. Biol. 203, 803-816 (1988).

28. Carson, M. K. J. appl. Crystallogr. 24, 958-961 (1991)

29. Garcia, A. \& Giegé, R. Biochem. biophys. Res. Commun. 186, 956-962 (1992).

ACKNOWLEDGEMENTS. We want to express our gratitude to the late 3 . P. Ebel. His continuous support from the beginning was decisive for the success of the project. We thank M. Boeglin, M. Delarue, A. Mitschler and A. Poterszman for unpublished data on the ternary complex and on the Thermus thermophilus AspRS, G. Eriani, J. Gangloff, R. Giégé, D. Kern, J. Pütz and J. Rudinger for discussions and $J$. Arnez for his comments on the manuscript. This work was supported by grants from the Human Science Frontier Program and the EEC Science Program.

\title{
CORRECTION
}

\section{Lead isotope evidence for young trace element enrichment in the oceanic upper mantle}

\author{
Alex N. Halliday, Gareth R. Davies, Der-Chuen Lee, \\ Simone Tommasini, Cassi R. Paslick, \\ J. Godfrey Fitton \& Dodie E. James
}

Nature 359, 623-627 (1992)

WE have been unable to precisely reproduce some of the lead isotope data for Madeira lavas reported in the above paper. In the light of further analyses the correct compositions are as follows:

$\begin{array}{lccc}\text { Sample } & & & \\ \text { number } & { }^{206} \mathrm{~Pb} /{ }^{204} \mathrm{~Pb} & { }^{207} \mathrm{~Pb} /{ }^{204} \mathrm{~Pb} & { }^{208} \mathrm{~Pb} /{ }^{204} \mathrm{~Pb} \\ \text { MD4 } & 19.159 & 15.533 & 38.825 \\ \text { MD10 } & 19.182 & 15.535 & 38.864 \\ \text { MD32 } & 19.097 & 15.559 & 38.946 \\ \text { MD40 } & 19.143 & 15.573 & 38.864 \\ \text { MD64 } & 19.038 & 15.556 & 38.753\end{array}$

The ${ }^{207} \mathrm{~Pb} /{ }^{204} \mathrm{~Pb},{ }^{87} \mathrm{Sr} /{ }^{86} \mathrm{Sr}$ and ${ }^{143} \mathrm{Nd} /{ }^{144} \mathrm{Nd}$ ratios still plot within the field of Atlantic MORB, whereas the ${ }^{206} \mathrm{~Pb} /{ }^{204} \mathrm{~Pb}$ and ${ }^{208} \mathrm{~Pb} /{ }^{204} \mathrm{~Pb}$ ratios are relatively high for MORB. Therefore, although the revised $\mathrm{Pb}$ isotopic compositions plot closer to other OIB, the overall interpretation is unchanged. 